\title{
İSLAM HUKUKU BAKIMINDAN GAYRIMÜSLIM ÜLKELERE HİCRET
}

\begin{abstract}
Ahmet EKŞiं
Öz

Peygamberimiz ve ilk Müslümanların Mekke'den Medine'ye hicreti, İslam tarihinin en önemli olaylarından biridir. Bu nedenle hicret, çok yönlü incelenmesi gereken bir konudur. Bu çalışmada fikhî bakımdan inceleyeceğimiz hicret, tarihin seyrini değiştiren ve asırlar ötesini etkileyen önemli bir olaydır. Tarihte önemli bir dönüm noktası olan hicretin, siyasi ve sosyal sonuçları kadar doğurduğu fıkhî sonuçları da önem arz etmektedir. Bu bağlamda başta hicretin hükmü olmak üzere, hicret neticesinde Müslümanların kendine özgü bir yurt edinmelerinin literatüre kattığı dâru'l-harp/küfr-dâru'l-İslam terimleri ve buralarda yaşayan Müslümanların dini hayatlarına dair hükümler gibi pek çok fikhî mesele hicretle bağlantılı olarak tartışılmaktadır. Konunun genişliği düşünülerek bu çalışmada sadece hicretin hükmü ve bu bağlamda günümüzde yaşadıkları ülkelerden çeşitli nedenlerle göç etmeye mecbur edilen Müslümanların gayrimüslim ülkelere hicretinin hükmü ele alınarak incelenmiştir.
\end{abstract}

Anahtar kelimeler: İslam Hukuku, Hicret, Hüküm, Dâru'l-İslam, Dâru'l-harb.

\section{THE MIGRATION (HIJRA) TO NON-MUSLIM COUNTRIES IN TERMS OF ISLAMIC LAW}

\begin{abstract}
One of the most important events in the history of Islam is the Hijra, migration of our Prophet and first Muslims from Mecca to Medina. Therefore, it is an an important subject to be examined and studied from many different aspects This migration that we will examine in terms of jurisprudence in this study is an important event that changed the course of history and had long lasting impact for centuries. This important turning point in the history had legal consequences that are as important as its social and political consequences. These legal consequences such as the concepts of dar al-harb, dar al-kufr and dar al-Islam, which are new contributions to the Islamic legal literature as a result of Muslim's having their own country after the Hijra, and judgments related to Muslim living in those places are discussed in connection with the Hijra. Considering the vastness of the topic, in this study, we focused on the judgment of the Hijra of the Muslims who are forced out of their country due to various reasons to live in non-Muslim countries.
\end{abstract}

Keywords: Islamic Law, Immigration (Hijra), Judgment, Dâr al-Islam, Dâr al-harb.

\section{Giriş}

Etki oranı aynı olmamakla birlikte tarihte insan hayatına tesir eden pek çok önemli olay vardır. Bunlardan biri de insanlığın çeşitli vesilelerle şahit olduğu ve 
hemen hemen bütün peygamberlerin de maruz kaldığı, hicrettir. Zira Peygamberlerin pek çoğu gönderildikleri toplumlar veya kavimleri tarafından hicret etmeye maruz bırakılmışlardır. Onlar da kendilerine inananlarla birlikte yurtlarını ve oradaki varlıklarını terk ederek hicret etmişlerdir. ${ }^{1}$ Inkârcılar ise yurtlarında helak edilmişlerdir. "Kâfir olanlar peygamberlerine dediler ki: 'Elbette sizi ya yurdumuzdan çıkaracağız ya da mutlaka dinimize döneceksiniz!' Rableri de onlara: 'Zalimleri mutlaka helâk edeceğiz!' diye vahyetti."2 ayeti bu tarihi realiteyi dile getirmektedir. ${ }^{3}$

Tıpkı diğer peygamberler gibi Hz. Peygamber ve ona inananlar da benzer sebeplerden dolayı ana yurtları olan Mekke'yi terk ederek hicret etmek zorunda kaldılar. İslam tarihinde bilinen ilk hicret bazı Müslümanların Habeşistan'a göç etmesiyle gerçeklești. Daha sonra Allah'ın hicret emriyle Peygamber (s.a.v.) ve Müslümanlar Medine'ye göç ettiler. 622 yılında gerçekleşen bu kutsal göç hareketine "hicret" denir. Hicretle beraber Müslümanlar kendileri için güvenli bir ortama kavuşmuş oldular.

Hedefini ilahi iradenin çizdiği her hicret muhacirler için hep yeni firsatları ve imkânları da beraberinde getirmiștir. Hz. İbrahim, Hz. Musa, Hz. Lut ve Hz. Salih gibi daha birçok peygamber ve onlara inananlar kavimlerinin baskı ve zulümlerinden hicret sayesinde kurtulmuşlar ve tebliğlerini sürdürecek yeni yurtlar edinmişlerdir. Müslümanlardan bir kısmı Habeşistan'a hicretle can güvenliğine kavuşmuşlar, Medine'ye hicretle ise kendilerine güvenli bir yurt bulmuşlardır.

Peygamber (s.a.v.)'in Medine'ye hicreti, sonuçları itibariyle tarihin en önemli olaylarından biridir. Vahyin ilk muhatapları olan Hz. Muhammed (s.a.v.)'in ilk öğrencileri ve aynı zamanda arkadaşları ilk İslâm toplumunu Medine'de oluşturarak İslam dinini buradan diğer bölgelere yaymışlardır. Hicretle aydınlanan Yesrib Medine adını alarak dünyanın en parlak medeniyetinin merkezi olmuştur. ${ }^{4}$

Dünya tarihinde gerçekleşen büyük değişimler, birtakım ağır yaşam şartlarının zorladığı göç hareketleriyle yakın ilişkilidir. Zira büyük medeniyetlerin doğuşu, büyük göç hareketleriyle ve göçmenler eliyle gerçekleştirilmiştir. Hz. Osman döneminde Medine'den diğer beldelere yaşanan göç ile doğudan batıya doğru yaşanan kavimler göçü bu yargıyı destekleyen en önemli somut örneklerdendir. Bu anlamda Medine'ye hicret de ilk Müslümanlar için sadece güvenli bir yurt arayışından öte yeni bir toplum ve medeniyet inşası gibi daha önemli ve büyük hedefler için bir başlangıç olmuştur. ${ }^{5}$

Mehmet Demir, "Bir İtaat Eylemi Olarak İslâm'da Hicret ve Muhacirler", İlahiyat Akademi Dergisi, 3/4 (2016), 159.

İbrahim 14/13.

Diğer ayetler için bkz. A'râf 7/88, Yûnus 10/90, Hûd 11/80-81, İbrahim 14/13, Hicr 15/65, İsrâ 17/76-77, Tâhâ 20/77-78, Şuarâ 26/52-67, Ankebût 29/26.

Adnan Demircan, “Hz. Peygamberin Hicreti”, İslam Tarihi Araştırmaları Dergisi, 1/1 (2017), 1.

Âdem Apak, "Hz. Peygamber'in Hicret Sonrası Medine'de Örnek Toplum Olușturma Adımları Üzerine”, Hz. Muhammed ve Evrensel Mesajı Sempozyumu, Nisan, 20-22 2007 (Yay. Haz. Mahfuz Söylemez), Ankara: İslami İlimler Dergisi Yayınları, 2007, s. 317. 
Müslümanların güvenli bir yurt arayışının sonucu olan hicret, zulümden kurtuluş, İslam devletine doğru atılan bir adım ve yeni bir topum inşası gibi büyük hedeflerle gerçekleșen bir göç hareketidir. Tarihte önemli bir dönüm noktası olan hicretin, siyasi ve sosyal sonuçlarının yanı sıra birtakım fıkhî sonuçları olmuştur. Başta hicretin hükmü olmak üzere, hicret neticesinde Müslümanların kendine özgü bir yurt edinmelerinin literatüre kattığı dâru'l-harp-dâru'l-İslam ve buralarda yaşayan Müslümanların dinî hayatlarına dair hükümler gibi pek çok fikhî mesele hicretle bağlantılı olarak tartışılmaktadır. Bu çalışmada sadece mükellefiyet, zaman ve şartları bakımından hicretin hükmü ele alınacaktır. Hicretle bağlantılı olarak tartışılan diğer fıkhi hükümlere, konunun genişliği dolayısıyla, bu çalışmada yer verilmeyecektir.

\section{Kavramsal Çerçeve}

\subsection{Hicret}

Sözlükte, terk etmek, bırakmak, ayrılmak, göç etmek, ilgisini kesmek anlamında هجْر ـهجر ان mastarından isim olan hicret, insanın bedenle, dille veya kalp وصل ile başkasından ayrılmasıdır. ${ }^{6}$ Aynı zamanda birleştirmek anlamındaki kelimesinin zıddı olan hicret, bulunduğu yerden çıkıp başka bir mekana gitmektir."7 Terim olarak hicret ise kafirler arasındaki vatanı terk edip İslam yurduna göçmektir. ${ }^{8}$ Bütün bu genel anlamlarının yanı sıra hicret daha özel bir anlamda Peygamber (s.a.v.) ve ashabının 622 yılında Medine'ye göç etmesi için kullanılan bir terimdir. ${ }^{9}$ Bu nedenledir ki Medine için kullanılan bir çok ismin yanı sıra bu tarihten itibaren "Dâru'l-hicret=Hicret yurdu" da bir isim olarak literatürdeki yerini almıştır.10 Ancak bu tariflerin Mekke'nin fethine kadar gerçekleşen hicretle sınırlı olduğu gözden uzak tutulmamalıdır. Zira özellikle Mekke'nin fethinden sonra hicretin anlam alanının genişlediği görülür. Nitekim zulmü, ma'siyeti, günahı ve haramları terk etmek ve bunlardan uzak yaşanabilecek yerlere göç etmek de hicret olarak nitelendirilmiştir.11 Bu son anlamıyla hicret, benzer şartlarda kıyamete kadar devam edecek göçleri de kapsamaktadır.

Kur'an'da "hicret" kelimesi geçmemektedir, ancak bu kelimenin (هجر) "hecr" kökünden türeyip "yalnız bırakmak"12, "uzaklaşmak"13, "bir kişi veya gruptan

\footnotetext{
6 Ebü'l-Kâsım Hüseyin b. Muhammed Ragıb el-İsfahanî, "Hcr” md., el-Müfredat fí garibi'l-Kur'an, (thk. Muhammed Seyyid Kilani), Beyrut: Dâru'l-marife, t.y., s. 536.

Ebü'l-Fazl Muhammed b. Mükerrem b. Ali el-Ensârî İbn Manzur, "Hcr" md., Lisanü'l-Arab, Beyrut: Dâru Sadr, h. 1414, V, 1662.

Seyyid Şerfi Cürcani, "Hicret” md., et-Ta'rifat, Beyrut: Dâru'l-kütübi'l-ilmiyye, 1983, s. 256.

Ahmet Önkal, "Hicret", TDV İslâm Ansiklopedisi (DİA), XVII, 458.

Bkz. Ebû Abdullah Muhammed b. İdris b. Abbas Șafii, el-Ümm, Beyrut: Dâru'l-marife, 1990, VI, 142.

11 Ekmeleddin Muhammed b. Muhammed b. Mahmûd b. Ahmed Babertî, Inaye şerhi'l-hidaye, Beyrut: Dâru'l-fikr, t.y., I, 349.

12 Nisa $4 / 34$.

$13 \quad$ Meryem 19/46.
} 
ayrılmak"14, "göç etmek"15, "ayrılmak"16, "kötü şeyleri terk etmek"17 ve "hakaret etmek"18 anlamında türevleriyle birlikte toplam otuz bir yerde geçmektedir. Bazı ayetlerde ise ıstılah anlamına muvafık olarak "Allah emri doğrultusunda kendi vatanını terk ederek başka bir beldeye göç etmek" manasında kullanılmıştır:

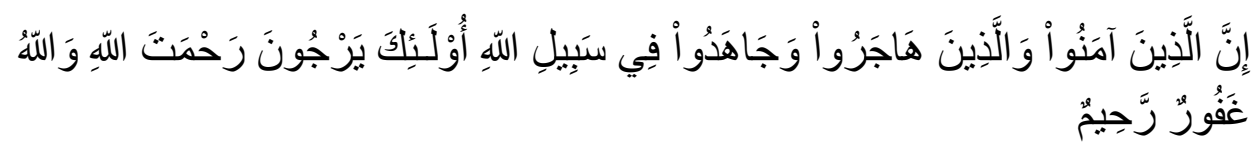

"Iman edenler ve hicret edip Allah yolunda cihad edenler var ya, iște bunlar, Allah'ın rahmetini umabilirler. Allah, gafûr ve rahîmdir."19

Hicret edenler anlamına gelen ve çoğulu muhâcirîn olan Muhâcir kelimesi ayetlerin çoğunda Mekke'den Medine'ye hicret eden Müslümanlar için kullanılmaktadır. Bu ayetlerden biri şöyledir:

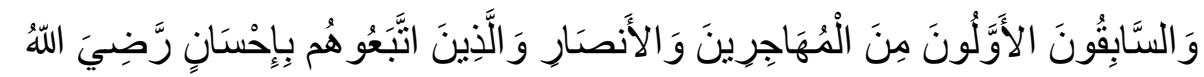

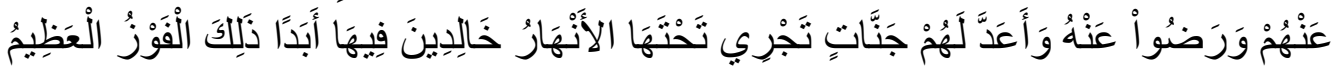

"(İslâm dinine girme hususunda) öne geçen ilk Muhacirler ve Ensar ile onlara güzellikle tabi olanlar var ya, işte Allah onlardan razı olmuştur, onlar da Allah'tan razı olmuşlardır. Allah onlara, içinde ebedî kalacakları, zemininden ırmaklar akan cennetler hazırlamıştır. İște bu büyük kurtuluştur." 20

Kur'an-ı Kerim'de daha çok hicret edenlerle onların gerçekleştirdikleri bu kutsal yolculuğun önemine dikkat çekilmiştir. Hadislerde ise Mekke'den Medine'ye göç olayına işaret edilmekle birlikte kötülükleri terk etme ve onlardan uzak durma gibi farklı anlamlarda kullanıldığı da görülmektedir. ${ }^{21}$ Meselâ bir hadiste, 'Muhacir Allah'ın yasakladığı kötülük ve günahları terk eden kimsedir.'22 buyrulmaktadır. Bir diğer hadiste de hicretin 'kötü şeyleri terk etmek' anlamına geldiği belirtilmektedir. ${ }^{23}$ Hadislerde hicretle ilgili dikkat çeken vurgulardan biri de hicretin önemi, fazileti ve hicret edenlerin Allah katındaki değeridir. Bu hadislerden birinde şöyle buyrulur: "Cennette yüz derece bulunmaktadır. Allah (cc) onları muhacirler ve yolunda cihat eden mücahitler için hazırlamıştır..."24

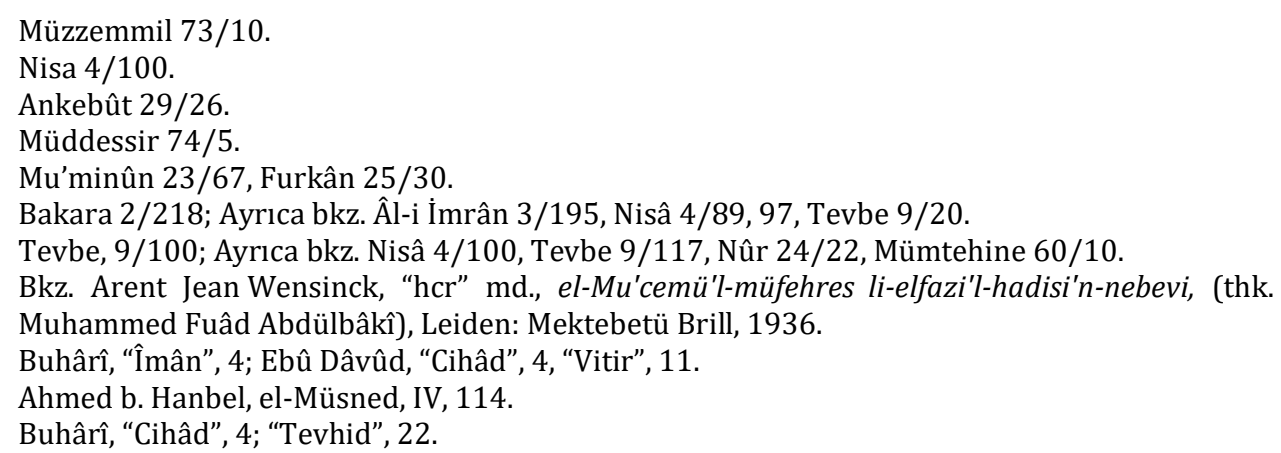


Fıkıh ilminde, çoğunlukla İslam şeriatini öğrenmek veya Müslüman olmak için dâru'l-harpten dâru'l-İslama göç etmek anlamında kullanılan ${ }^{25}$ hicret İslam âlimleri tarafından farklı şekillerde tasnife tabi tutulmuştur. Bu tasniflerden en detaylı olanlarından biri İbn Dakikü'l-îd (702/1302)'e aittir. Bu tasnife göre hicret; Sahabenin Habeşistan'a hicreti, Peygamberimizin kendisine inananlarla birlikte Medine'ye hicreti, İslam'ı öğrenmek için civar kabilelerden Medine'ye gelenlerin ve sonra da kendi vatanlarına dönenlerin hicreti, Müslüman olmak için Mekke'den Medine'ye gelip sonra Mekke'ye geri dönenlerin hicreti ve Allah'ın nehyettiklerinden uzaklaşanların kötülüklerden kaçınma şeklindeki hicreti olmak üzere beş kısımda ele alınmıştır. İbn Dakikü'l-îd bu taksimi yaptıktan sonra “Ameller niyetlere göredir..." 26 hadisinde söz konusu edilen hicretin hicret çeşitlerinin tamamını kapsadığını ifade etmektedir. ${ }^{27}$ İbn Kayyim el-Cevziyye (ö. 751/1350) ise hicreti biri bedenen bir beldeden başka bir beldeye hicret, diğeri de kalben Allah ve Resulüne hicret olmak üzere iki kısımda daha muhtasar olarak ele alır. ${ }^{28} \mathrm{Bu}$ durumda birinci tasnifin ilk dört çeşidini İbn Kayyim'in tek başlık altında topladığını görüyoruz. Konunun amacı ve sinırlılıkları nedeniyle birinci tasnifte Allah'ın nehyettiklerinden uzaklaşmak, ikinci tasnifte ise kalben Allah ve resulüne hicret etmek şeklinde belirtilen kısımlar bu çalışmanın dışında tutulacaktır. Ayrıca hicreti hüküm bakımından incelemeyi hedefleyen bu çalışmada hicret, Habeşistan'a hicret, Medine'ye hicret, Mekke'nin Fethi'nden sonra hicret ve gayrimüslim ülkelere hicret olmak üzere dört başlık altında ele alınacaktır. Ancak bunun öncesinde her hicret fiiliyle bir terkedilen bir de gidilen mekân anlamında ülke kavramından da kısaca söz etmek gerekmektedir.

\section{2. Ülke}

İslam hukuku kaynaklarında daha çok "dâr" kavramıyla ifade edilen ülke, millet ve egemenlik ile birlikte devletin üç temel unsurundan birini oluşturur. Kaynaklarda yaygın olarak kullanıldığı için bu çalışmada da çoğunlukla ülke yerine dâr terimi tercih edilmiştir. Sözlükte, bina, arsa, mahalle, şehir, yurt ve belde anlamına gelen dâr ${ }^{29}$, Kur'an'da mesken ${ }^{30}$, cennet ${ }^{31}$, cehennem ${ }^{32}$ ve Hicret Yurdu/Medine ${ }^{33}$ olmak üzere genel olarak dört anlamda kullanılmıştır. ${ }^{34}$ İslam

25 Ebu Bekr Muhammed b. Ahmed b. Ebî Sehl es-Serahsî, el-Mebsut, Beyrut: Dâru'l-marife, 1993, IX, 135.

Buhârî, "Vahy”, 1.

27 Ebü'l-Feth Taklyyüddin Muhammed b. Ali İbn Dakikul'id, Ihkamü'l-ahkâm şerhi Umdeti'lahkâm, Beyrut: Âlemü'l-Kütüb, 1987, I, 62.

28 Ebû Abdullah Şemseddin Muhammed İbn Kayyim el-Cevziyye, er-Risâletü't-tabukiyye: Zadü'lmuhacir ila Rabbihi, (thk. Mahmud Cemil Gazi), Cidde: Mektebetü'l-medeni, t.y., s. 16.

İbn Manzur, Lisanü'l-Arab, II, 1450-1452.

A'râf 7/78, 91.

Nahl 16/30.

İbrâhîm 14/28.

Haşr 59/9.

Ebü'l-Ferec Cemâlüddîn Abdurrahmân b. Alî b. Muhammed Bağdâdî İbnü'l-Cevzi, Zadü'lmesir fí ilmi't-tefsir, (thk. Abdü'r-Rezzâk el-Mehdî), Beyrut: Dâru'l-kütübi'l-Arabiyye, h. 1422, II, 136, 513, 557; IV, 258. 
hukuku terimi olarak dâr, bir siyasi otoritenin hakimiyeti altında bulunan ülke anlamına gelmektedir. ${ }^{35}$ Fıkıh literatüründe daha çok "İslam-harb" kelimelerine izafetle dâru'l-İslam ve dâru'l-harb/dâru'l-küfr şeklinde kullanılmaktadır. Dâr kelimesine izafe edilen İslam ve harb/küfr o ülkede uygulanan hükümlerle alakalıdır. Müslüman idarecinin idaresi altında olup İslam'ın hükümlerinin cari olduğu ülkeye dâru'l-İslam; gayrimüslim idarecinin emri altında onun emirlerinin yürürlükte olduğu ülkeye dâru'l-harb/dâru'l-küfr denilmektedir. ${ }^{36}$ Ancak Ebu Hanife farklı bir yaklaşımla dâr kelimesine izafe edilen "İslam-küfr"den maksadın güven ve korku olduğunu söyler. Bu durumda ona göre Müslümanların güvende olduğu yer dâru'l-İslam güvende olmadığı yerler ise dâru'l-küfürdür. ${ }^{37}$ Yine Ebu Hanife'ye göre dâru'l-İslam olan bir belde ancak; ülkenin küfrün hakimiyetine girmesi, dâru'l-küfre komşu olması ve Müslümanlar için güven ve emniyetin kalmaması şartlarının bir arada bulunması halinde dâru'l-küfre dönüşür. ${ }^{38} \mathrm{Ebu}$ Hanife'nin güven-korku esasına dayalı bu taksiminin ileride tartışılacak olan gayrimüslim ülkelere hicret açısından ayrıca önem arz ettiği kanaatindeyiz.

Hukuki anlamda hakimiyeti esas alan Malikiler, gayri muslimlerin hükümlerinin geçerli olduğu yerleri dâru'l-harb; İslam'ın ahkâmını cari olduğu yerleri ise dâru'l-İslam olarak kabul ederler. ${ }^{39}$ Ezan ve cemaatle namaz gibi İslam'ın şiarlarının kaim olduğu bir yer, kafirlerin orayı zorla almasıyla dâru'l-harb olmaz; fakat İslam'ın şiarları kesintiye uğrayıp da küfür hükümleri uygulanmaya başlandığında orası dâru'l-harb olur. ${ }^{40}$

Müslümanların hakimiyetinde olan, Müslümanların çoğunlukta olduğu veya azınlıkta olsalar bile dinlerini izhar edebildikleri ve fitneden emin oldukları ülkeler ile hiçbir Müslüman bulunmasa bile Müslüman devlet başkanının hakimiyetinde olan ülkeler dâru'l-İslam sayılır. Şafîilere göre bir kere dâru'l-İslam olan bir yer bir daha dâru'l-harbe dönüşmez. Kâfirler Müslümanların bölgesine tamamen hâkim olsa, oradan Müslümanları sürse ve orada küfür hükümlerini uygulasalar bile orası dârul-İslam olmaktan çıkmaz.41

"Şafiiler'in konuyla ilgili açıklamaları dikkate alındığında, halkın Müslüman olduğu ancak kafirlerin istila ettiği yerlerde siyasi hakimiyetin; Müslümanların fethettiği ancak cizye karşllı̆̆ında gayrimüslim halkı

\footnotetext{
35 Ahmet Özel, İslam hukukunda ülke kavramı dâru'l-İslam dâru'l-harb, İstanbul: İz Yayıncılık, 2011, s. 73.

36 Muhammed b. A'la b. Ali el-Faruki el-Hanefi Tehânevî, Keşşafu istılahati'l-fünun, (thk. Ali Dehruc), Beyrut: Mektebetü Lübnan, 1996, I, 779.

37 Alâuddin Ebu Bekr b. Mes'ud el-Kâsânî, Bedâi'u's- sanâi' fi tertibi'ş-șerai', Beyrut: Dâru'lkütübi'l-ilmiyye, 1986, VII, 131.

38 Kâsani, Bedai, VII, 130.

39 Ebu'l-Velid Muhammed b. Ahmed b. Muhammed İbn Rușd el-Kurtubî, el-Mukaddimâtü'lmümehhidât, (thk. Said Ahmed A'râb), Beyrut: Daru'l-Garbi'l-İslami, 1988, II, 153.

40 Muhammed b. Ahmed b. Arafe ed-Desukî, Hâşiyetü'd-Desûkî ala şerhi'l-kebîr, Beyrut: Dâru'lfikr, t.y., II, 188.

41 Şemseddin Muhammed b. Ahmed b. Hamza el-Ensârî Remlî, Nihayetü'l-muhtac ila şerhi'lminhac. Beyrut: Dârü'l-Fikr, 1984, VIII, 82.
} 
topraklarında bıraktıkları yerlerde ise hukuki hakimiyetin mevcut olmadığı ya da en azından belli oranda eksildiği, buna rağmen dâru'-İslam sayıldıkları görülecektir." 42

Hanbelilerde ise dâru'l-İslam ve dâru'l-harb ayrımında temel kriterin nüfus ve hakimiyet olduğu görülmektedir. Zira Müslümanların yerleștiği ve İslam ahkamının cari olduğu ülkeler dâru'l-İslam'dır. ${ }^{43}$ Dolayısıyla dâru'l-İslam'da küfür hükümleri uygulanmaya başlandığında orası daru'l-harp olur.

Bütün bu görüşlerden hareketle bir yerin ilk olarak daru'l-İslam'a dönüşmesi için İslamî hükümlerin uygulanmasının şart olduğu konusunda fukahanın ittifak ettiği söylenebilir. Ancak dâru'l-İslam olan bir ülkenin dâru'l-harbe dönüşmesi konusunda ise birincisi Ebu Hanife'ye, ikincisi Şafiilere ve üçüncüsü ise Hanbeliler ile Malikilere ait olan üç farklı yaklaşımdan söz edilebilir. Birinci yaklaşıma göre küfre ait hükümlerin uygulanması, dâru'l-küfre bitişik olması, Müslümanların güvenliğinin kalmaması durumunda dâru'l-İslam dâru'l-küfre dönüşür. İkinci yaklaşıma yani Şâfifilere göre bir kere daru'l-İslam olan bir yer bir daha daru'l-harbe dönüşmez. İmam Mâlik ve Ahmed bin Hanbel'e ait olan üçüncü yaklaşıma göre ise daru'l-İslam'da küfür hükümleri uygulanmaya başlandığında orası daru'l-harp olur.

Dâru'l-harp, biri dâr diğeri geniş olmak üzere iki anlamda kullanılmaktadır. Dar manada, İslam ülkesiyle veya Müslümanlarla savaş halinde bulunan ülke; geniş manada ise İslam ülkeleri dişında kalan bütün yabancı ülkeler anlamına gelmektedir. ${ }^{44}$ Kaynaklarda Müslümanlarla savaş halinde bulunanlar için özelde "dâru'l-harb" tabiri kullanılırken süreli veya süresiz anlaşmalara göre de dâru'ssulh/dâru'l-muahede ve dâr'u-muhayede isimleri kullanılmaktadır. Diğer taraftan fıkıh literatüründe devlet başkanına veya yönetimine karşı çıkarak isyan edenlerin hâkim oldukları bölgeler için dârü'l-bağğ ${ }^{45}$ bunun dışında kalan bölgeler için ise dârü'l-adl tabirlerinin kullanıldığına rastlamak mümkündür. ${ }^{46}$ Diğer taraftan klasik dönem fıkıh eserlerinde yapılan dâru'l-harb ve dâru'l-İslam tanımlarının günümüz dünyasında Müslümanların karşı karşıya kaldıkları sorunların çözümünde yetersiz kaldığı görülmektedir. Bu bağlamda Tahir b. Âşur'un "et-Tahrir ve't-tenvîr" adlı eserinde altı maddede sunduğu yaklaşım, bu konudaki sorunların çözümüne önemli ölçüde katkı sağlayacağı düşüncesiyle ilgili kısmı özetleyerek buraya almakta fayda görmekteyiz.

Tâhir b. Âşûr Müslümanların yaşadığı ülkeleri hicretin hükmü bakımından altı kısma ayırır. Bunlar:

42 Muammer Arangül, Fıkıh Literatüründe Klasik Ülke Terminolojisi ve Güncel Değeri, Şırnak Üniversitesi İlahiyat Fakültesi Dergisi, 2017/2, s. 16.

43 Bkz. Ebu Abdullah Şemseddin Muhammed İbn Kayyim el-Cevziyye, Ahkâmu ehli'z-zimme, (thk. Yusuf b. Ahmed el-Bekri ve Şakir b. Tevfik el-Aruri), Demmam: Ramadi li'n-neşr, 1997, II, 728.

44 Ahmet Özel, İslam hukukunda ülke kavramı dâru'l-İslam dârulharb, İstanbul: İz Yayıncılık, 2011, s. 73.

45 Ebü'l-Hasen Alî b. Muhammed b. Habîb Basrî Maverdi, el-Ahkâmü's-sultaniyye, Kahire: Dâru'lhadis, t.y., s. 100.

46 İbrahim Abdullah Selkînî, el-Hicretü ve ahkâmuha, Lübnan: Dâru’n-Nevadir, 2014, s. 133. 


\begin{abstract}
"Baskı yoluyla müminlerin dinlerinden döndürülüp başka dinlerine girmeye zorlandığı ama müminlerin oradan hicret etmelerinin mümkün olduğu ülke; inanç bakımından bir engelleme ve baskı olmamakla birlikte Müslümanların can, mal namus gibi değerlerinin güvende olmadığı ülke; günümüz Hristiyan batı ülkelerinde olduğu gibi inanç yönünden baskı yapılmayan; can, mal ve namus bakımından da güvenli olduğu halde Müslümanlara, kendi hukuklarını uygulama imkânı verilemeyen ülkeler; yine küfrün hakim olduğu fakat Müslümanlara, kendi dinlerine ait hukuk kurallarına uygun hareket etmelerine izin verilen ülkeler; halkın inancına ve dinin esaslarına saygı duyulan ve yöneticileri Müslümanlardan olan; fakat yönetimi gayrimüslimlerin kontrolünde bulunan yani manda durumundaki İslâm ülkeleri ve Müslümanlara baskı yapılmamakla beraber alenen İslâm dinine aykırı uygulamaların görüldüğü, ahlâka muğayir davrananlara karşı sadece sözlü uyarıya imkân verilen, bazen buna da izin verilmeyen ülkeler."47
\end{abstract}

Çağdaş İslam hukukçularından Vehbe Zühaylî klasik dönem fukahanın ülke taksiminde vakıadan hareket ettiklerini dolayısıyla yaptıkları taksimin şeri anlamda bir kesinliğinin olmadığını ifade ederek ülkeleri dâru'l-İslam ve dârü'l-ahd olarak taksime tabi tutmaktadır. Bu taksime göre Müslümanların yaşadığı ve hâkim olduğu ülkeler dâru'l-İslam diğerleri ise dârü'l-ahddır. Zühayli'ye göre asıl olan barıștır, savaş geçicidir. Bu nedenle geçici duruma göre bir isimlendirmede bulunmak doğru olmadığı için dâru'l-harb tabirini kullanmadığını söyler. Bu görüşüyle Ebu Hanife ile benzeştiğini ifade eder. Zira Ebu Hanife de ülke ayrımında savaş ve hakimiyetten ziyade güven ve emniyeti esas aldığını vurgular. ${ }^{48}$ Yusuf el-Kardavi ise İslam ülkelerini dâru'l-İslam, diğer bütün ülkeleri dârü'l-ahd ve İslam beldelerini işgal eden siyonist ülkeleri ise dâru'l-harb olarak nitelendirerek üçlü bir taksim yapmaktadır. 49

Bütün bu tanımlar incelendiğinde temel ayırt edici unsurun hakimiyet, güven ve emniyet olduğu dikkat çekmektedir. Dolayısıyla bir ülkede yaşayan nüfusun çoğunluğunun Müslüman veya gayrimüslim olmasından ziyade hakimiyetin kimin elinde olduğu ve Müslümanların can, mal ve namus bakımından güvende olup olmadığı, o ülkenin dâru'l-İslam veya dâru'l-harb olmasında önemli bir ölçüttür.

Fıkıh literatüründe dâru'l-harp-dâru'l-İslam bağlamında tartışılan konuların başında hicret gelmektedir. Zira buralarda yaşayan Müslümanların ibadet hayatları, bulundukları bölgenin halkıyla münasebetleri, savaşlara katılma, ganimetlerden pay alma gibi daha pek çok fıkhî mesele hicretle bağlantılı olarak tartışılmaktadır. Günümüzde Müslümanların çoğunluk veya azınlıkta bulunduğu birçok yerde ülke yönetimiyle yaşadıkları problemler yeni şartlar oluşturmakta, bazen bu şartlar Müslümanları bulundukları yerlerden göç etmeye mecbur etmektedir.

\footnotetext{
47 Muhammed Tahir b. Muhammed b. Muhammed et-Tunusi İbn Aşur, et-Tahrîr ve't-tenvîr, Tunus: ed-Dâru't-Tunisiyye, 1984, V, 178-180.

Vehbe Zühaylî, Asarü'l-harb fi'l-fikhi'l-İslâmî, Dımașk: Dârü'l-fikr, 1983, s. 194-195. sünne, Kahire: Mektebetu Vehbe, 2009, II, 900.
} 


\section{Hüküm Bakımından Hicret}

Müslümanların hayatında önemli bir dönüm noktası olan hicret, hakkı batıldan ayırmasıyla bir takvim başlangıc1 ${ }^{50}$, ayetlerin Mekkî ve Medenî olarak tasnifinde bir ölçü, namaz kıldıracak imamın tayininde bir öncelik sebebi ${ }^{51}$ olmanın yanı sıra teşri bakımından da büyük önem taşımaktadır. Nitekim namaz gibi bazı ibadetler hariç zekât, oruç, kurban, hac ve fitır sadakası gibi daha birçok ibadetin yanı sıra bireysel ve toplumsal hayatı düzenleyen hükümlerle devletler arası hukuka dair esasları içeren ayetler Medine'de nazil olmuştur. ${ }^{52}$ Böylesine önemli bir mihenk taşı olan hicretin hükmü de öteden beri fıkıhta tartışılan konuların başında gelmektedir. Özellikle Mekke'nin Fethi'nden sonra hicretin hükmü ile Müslüman bir ülkeden gayrimüslim bir ülkeye hicretin hükmü en çok tartışllan hususlar olmuştur.

Dinin bazı emirlerinin uygulanması Müslümanların içinde bulunduğu şartlarla ilintilidir. Başta imanı izhar etmek olmak üzere iyiliği emretme ve kötülükten nehyetme görevinin ifası, cuma ve bayram namazlarının edası gibi yükümlülükler bu konuda sağlanan serbestliklere bağlıdır. Bu nedenle küfrün hakimiyeti altında bulunan bir ülkede inancını açığa vuramayan, dininin gereklerini yerine getirme imkânı bulamayan; fakat bütün bunları gerçekleștirebileceği bir yere hicret etme fırsatı olan Müslümanlar için hicret farzdır. ${ }^{33}$ Zira "Kendilerine yazık eden kimselere melekler, canlarını alırken: 'Ne işte idiniz!' dediler. Bunlar: “Biz yeryüzünde çaresizdik' diye cevap verdiler. Melekler de: 'Allah'ın yeri geniş değil miydi? Hicret etseydiniz ya!' dediler. İște onların barınă̆ı cehennemdir; orası ne kötü bir gidiş yeridir." ${ }^{\prime 4}$ ayetindeki gibi şiddetli tehdit ancak ya haramı işleyenler ya da burada olduğu gibi vacibi terk edenler içindir. Bu ayetten istidlalle hicreti zorunlu kılan şartlar devam ettiği sürece hicretin farziyeti de devam eder. Peygamber (s.a.v.) "Fetihten sonra hicret yoktur." 55 şeklindeki uyarısından ise fetihle dâru'l-İslama dönüşen "Mekke'den hicret" etme yasağı anlaşılır. ${ }^{56}$ Ancak "Gerçekten zayıf ve güçsüz olan, çaresiz kalan ve hicret etmeye yol bulamayan erkekler, kadınlar ve çocuklar başkadır." ${ }^{57}$ ayeti hastalık, çaresizlik veya kafirlerin baskısı dolayısıyla hicret etme imkânı bulamayanları farz olan hükümden istisna etmektedir. ${ }^{58}$

Dâru'l-harbdan çıkma imkânı olduğu halde inancını açıklayabilen, dininin gereklerini yerine getirebilen, bu vesileyle bulunduğu bölgede İslam'ın yayılmasını ve bulunduğu yerden Müslümanlara bilgi akışını sağlayabilenler için hicret etmek zorunlu olmamakla birlikte müstehap görülmüştür. Zira Peygamber (s.a.v.), baskı

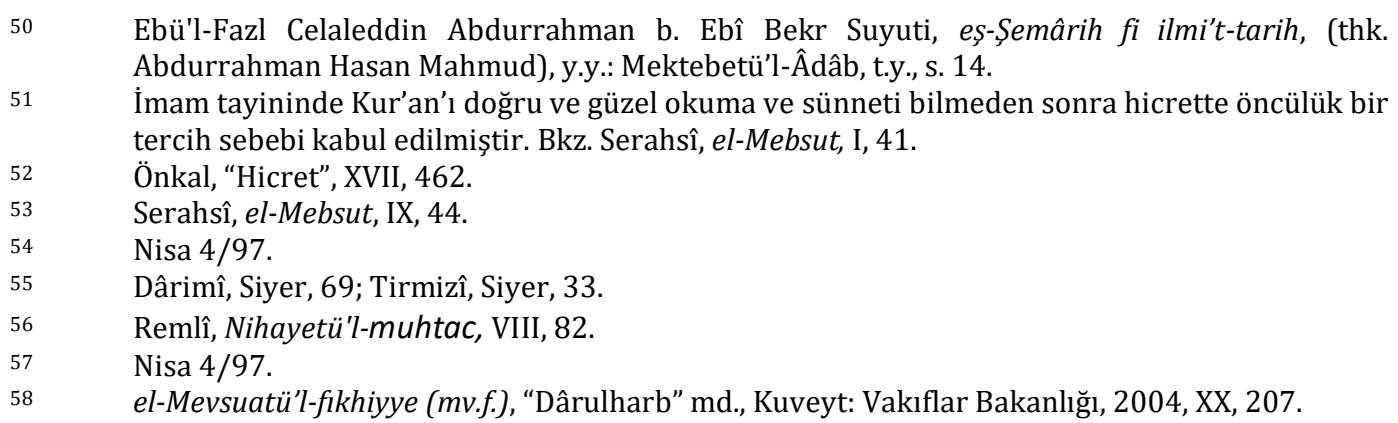


söz konusu olmadığı için Hz. Abbas'ın Mekke'de kalmasına izin vermiştir.59 İmam Şafîi dâru'l-harbda kendisine özel ve güvenli bir yer edinerek oradan İslam dinini yayma noktasında bir engelle de karşılaşmıyorsa böyle kimsenin hicret etmesinin haram olduğunu söyler. Diğer taraftan bir yerde Allah'a isyan ediliyorsa, oradaki Müslümanlar da bu durumu değiştiremiyorsa ve oradan da çıkma imkânı varsa hicret farz olur. Ama çıkmaya güç yetiremiyorsa hicretin vucubiyet hükmü düşer. ${ }^{60}$

Hicretin hükmüne göre ülkeleri altı gruba ayıran Âşur daha sonra bu ülkelerin durumuna göre hicretin hükmünü şu şekilde açıklar: Birinci grupta yer alan ülkelerden hicret etmek farzdır. İkinci grupta yer alan ülkelerde ise geçerli bir mazeret yoksa oralarda ikamet etmek caiz değildir. Üçüncü grup ülkelerde oturma hususunda ise Maliki mezhebinin önemli eserlerinden biri olan Müdevvene'den biri haram bir diğeri ise mekruh olmak üzere iki rivayet nakletmektedir. Dördüncü grupta yer alan ülkelerden hicret edenler de etmeyenler de kınanmazlar. Beşinci grupta yer alan niteliğe sahip olan ülkelerden hicret etmenin farz olmadığında şüphe yoktur. Her ne kadar son grupta yer alan ülkelerden hicret etmenin farz olduğunu söyleyen âlimler olsa da uygulamada aksi yönde tavır sergileyerek hicret etmeyen âlimler de olmuştur. Nitekim Fâtımîler döneminde Mısır'da bazı âlimler benzeri durumlarla karşı karşıya kalmasına rağmen bu âlimlerden hiçbiri ülkesinden hicret etmemiştir. Âşur bu son maddeyle ilgili şahsi kanaatinin inançları yönünden bir baskıya maruz kalmadıkları sürece Müslümanların bu nitelikteki ülkelerden hicret etmemeleri gerektiği yönünde olduğunu ifade eder. ${ }^{61}$

Gayrimüslim ülkelere göç ile orada yaşayan Müslümanların hukukî durumuyla ilgili görüşlerine mesnet teşkil etmesi bakımından Habeşistan'a, Mekke'den Medine'ye ve Mekke'nin fethinden sonraki hicrete değinmekte fayda görmekteyiz. Özellikle 19. asırdan itibaren sömürgeleştirilen İslam ülkelerinin hukuki durumunun Habeşistan modeliyle temellendirildiğini görmekteyiz. ${ }^{62} \mathrm{Bu}$ nedenle Habeşistan'a hicret konumuz açısından ayrı bir önem taşımaktadır.

\subsection{Habeşistan'a Hicretin Hükmü}

Mekke müşriklerinin önde gelen liderleri tarafından Müslümanlara uygulanan işkence ve eziyetler dayanılmaz hale gelince Peygamber (s.a.v.) Müslümanlardan bir kısmının, adil bir yönetimin olduğunu bildiği Habeşistan'a hicret etmesini istemiştir. Nübüvvetin beşinci yılında gerçekleșen bu küçük çaplı göç Müslümanların ilk hicreti olmuştur.

59 Ebû İshak Cemaleddin İbrâhim b. Ali b. Yusuf Şirazî, el-Mühezzeb fî fikhi'l-İmam eş-Şafii, Beyrut: Dâru'l-kütübi'l-ilmiyye, III, 265; Remlî, Nihayetü'l-muhtac, VIII, 82.

60 Ebû Zekeriyyâ Yahyâ b. Şeref b. Mürî Nevevî, Ravzatü't-talibîn, (thk. Adil Ahmed Abdülmevcud, Ali Muhammed Muavvaz), Riyad: Dâru âlemi'l-kütüb, 2003/1423, VII, 474-475.

61 İbn Așur, et-Tahrîr ve't-tenvîr, V, 178-180.

62 Muhammad Khalid Masud, "Gayr-i Muslim Bir Devlette Müslüman Olmak: Üç Alternatif Model”, İslam Hukuku Araştırmaları Dergisi, (Çev. Muammer Arangül), 18 (2011), s. 206. 
Başta can güvenliğini sağlama, dininin gereklerini yerine getirme, baskı ve zulümden kurtulma gibi şartların zorladığı bu hicret vahiyle taltif edilerek teşvik edilmiştir: "Allah yolunda hicret eden kimse yeryüzünde gidecek birçok güzel yer ve bolluk (imkân) bulur. Kim Allah ve Resulü uğrunda hicret ederek evinden çıkar da sonra kendisine ölüm yetişirse artık onun mükâfatı Allah'a düşer. Allah da çok bağışlayıcı ve esirgeyicidir. "“63

Talak suresinin “... Allah ona bir çıkış yolu ihsan eder.”64, “... Allah ona işinde bir kolaylı verir." 65 ve "... Allah, bir güçlükten sonra bir kolaylık yaratacaktır."66 ayetlerinde insan hayatına yön verecek bazı ilkelere yer verildikten sonra inanan insana bütün sıkıntılı olaylarda bu ilkelere göre hayatına çekidüzen vermesi gerektiği hatırlatılmaktadır. Nitekim İmam Şafii'ye göre Mekke'de müşriklerin baskılarından bunalan ilk Müslümanların Habeşistan'a hicret etmelerine izin verilmesi “... Allah ona bir çıkıs yolu ihsan eder." ayetinde belirtilen ilkenin bir tecellisidir. Zira Habeşistan'a hicret ederek bazı Müslümanların biraz olsun rahata kavuşmaları Allah'ın onlara lütfuyla ihsan ettiği bir çıkış yoludur. Bu şekilde Peygamber'in (s.a.v.) tavsiyesi doğrultusunda korku ülkesinden (dârü'l-havf) emniyet ülkesine (dârü'l-emn) gerçekleșen hicretin hükmü mendub olarak kabul edilmektedir. ${ }^{67}$

Allah ve Rasulü tarafından teşvik ve taltif edilmesi bakımından Müslümanların Habeşistan'a hicreti mendub olarak değerlendirilmekle birlikte Medine'ye hicretle düşünüldüğünde farklı hükümlere tabi tutuldukları görülmektedir. Nitekim bu iki hicretin farkını ortaya koyması bakımından Medine'ye hicretin farz, Habeşistan'a hicretin ise meşru olduğu ifade edilmektedir. ${ }^{68}$

Habeşistan'a yapılan göçün, "dâru'l-havf"dan "dâru'l-emn"e veya zulmün olduğu dâru'l-küfürden emniyetin olduğu dâru'l-küfre yapılan bir hicret olarak nitelendirilmesi ve buna Peygamber tarafından izin verilmiş olması ayrıca önem arz etmektedir. Zira bu hicret, sonraki dönemlerde özellikle günümüzde Müslümanların çoğunlukta olduğu ama güvenli olmayan ülkelerden Müslümanların azınlıkta olduğu fakat güvenli olan ülkelere hicretin meşruiyet tartışmalarına da önemli ölçüde ışık tutmaktadır.

\subsection{Mekke'den Medine'ye Hicretin Hükmü}

Hz. Peygamber'in hicretiyle Medine dışında kalan Müslümanlar için hicret bir zorunluluk haline gelmişti. Aynı zamanda imanla ilişkilendirilen bu emre uymayanlar kınanmış ve kendilerini kötü bir akıbetin beklediği bildirilmiştir. ${ }^{69}$

\footnotetext{
$63 \quad$ Nisâ $4 / 100$.

64 Talak $65 / 2$

65 Talak 65/4.

66 Talak 65/7.

67 el-Mevsuatü'l-fikhiyye (mv.f.), "Hicret” md., Kuveyt: Vizaretü'l-Evkaf ve'ş-Şuuni'l-İslâmiyye, 2004, XLII, 179.

68 Selkînî, el-Hicretü ve ahkâmuha, s. 60.

69 Nisâ $4 / 97$.
} 
"İman edip de hicret etmeyenler ise hicret edinceye kadar onlarla sizin hiçbir yakın dostluğunuz ve ilişskiniz olamaz." "70 ayetiyle de Müslümanlar, hicret etmeyenlere karşı takınacakları olumlu tavır konusunda uyarılmıștır. Zira Müslümanların Medine'de Peygamber (s.a.v.)'in etrafında kenetlenerek birlik oluşturmaları gerekiyordu. Allah Rasulü de Müslüman olmak üzere Medine'ye gelenlerden biat alırken onların Medine'de kalmalarını yani kendi yurtlarını terk ederek hicret etmelerini istiyordu. ${ }^{71}$ Nitekim "hicret ettikten sonra Mekke'ye dönüp orada ölen Sa'd b. Havle için çok üzülmüştü." ${ }^{72}$ Diğer taraftan Hz. Peygamber'in, "Allah'ım! Ashabımın hicretini kararlı kıl; onları topukları üzerinde geriye döndürme"73 şeklindeki duası bu dönemde yapılan hicretin ne kadar önemli olduğunu göstermesi bakımından ayrıca dikkate değerdir. Bütün bu ve benzeri naslarla gelen uyarı ve tavsiyelerden hareketle fukaha bu dönemde Medine'ye hicretin farz, oradan ayrılmanın ise haram olduğu hükmünü vermişlerdir. $\mathrm{Bu}$ hükmün en önemli sebeplerinden biri, Medine'deki Müslümanların sayısının az olması ve Rasülullah'ın onlara ihtiyaç duymasıdır. $\mathrm{Bu}$ ihtiyaç dolayısıyla Hanefîlere göre Medine'ye hicretin farziyeti Mekke'nin fethine kadar devam etmiştir. "Fetihten sonra hicret yoktur." 74 hadisi ise hicretin bu farz olan hükmünü neshetmiştir. ${ }^{75}$

Medine Dönemi'nin ilk yıllarında hicretin farz olmadığını söyleyen İmam Şafii aynı zamanda bu dönemde Mekke'de kalmaya devam etmenin de haram olmadığı kanaatindedir. Yine İmam Şafii'ye göre Medine'ye hicretten sonra cihat önce mubah ve daha sonra da farz kılınınca buna bağlı olarak hicretin hükmü de değişti. Nitekim Mekke'de kalıp hicret etmeyenlere baskı ve zulümler artınca hicrete gücü yetenlerin hicret etmeleri farz kılındı. ${ }^{76}$ Ancak "Erkekler, kadınlar ve çocuklardan (gerçekten) âciz olup hiçbir çareye gücü yetmeyenler, hiçbir yol bulamayanlar müstesnadır." 77 ayetinin mucebince hicrete güç yetiremeyenler bu hükümden istisna edilmiştir.

Hz. Muhammed (s.a.v.)'in Medine'ye hicret etmesiyle şu iki sebepten dolayı hicret diğer Müslümanlara da farz olmuştur:

Bunlardan birincisi Peygamberle ve Müslümanlarla beraber olarak onları desteklemek ve gücünü artırmaktır. Diğer bir sebep ise İslam'ı öğrenmek, yaşamak, öğretmek ve yaymak için elverişli olmayan ortamdan uzaklaşmaktır. Zira baskı, zulüm ve engellemelerin olduğu yerde oturmaya devam etmek dinî hayatı tehlikeye atmak demektir.78

\footnotetext{
$70 \quad$ Enfâl 8/72.

71 Buhârî, "Megāāî̀", 53; Müslim, “Birr”, 6.

72 Müslim, "Vaṣıyye", 5.

73 Müslim, "Vașıyye", 5.

74 Dârimî, "Siyer", 69; Tirmizî, "Siyer”, 33.

75 Serahsî, el-Mebsut, X, 6; Kâsani, Bedai, I, 158.

76 Remlî, Nihayetü'l-muhtac, VIII, 82; el-Mevsuatü'l-fikhiyye (mv.f.), "Hicret” md., XLII, 179.

$77 \quad$ Nisa $4 / 98$.

78 Hayrettin Karaman-Mustafa Çağrıcı-İbrahim Kâfi Dönmez-Sadrettin Gümüș, Kur'an Yolu, Ankara: Diyanet İşleri Başkanlığı Yayınları, 2006, II, 125.
} 
Mekke'nin fethiyle müşriklerin kontrol altına alınması birinci gerekçeyi ortadan kaldırmıştır. Bundan sonra hicretin farz olup olmaması ikinci gerekçe bağlamında düşünülmesi gerekmektedir. Bu düşünceye yön verecek olan en önemli kriter ise kişinin dinî hayatı olacaktır.

\subsection{Mekke'nin Fethinden Sonra Hicretin Hükmü}

Medine'de sağlanan birlik sayesinde güç kazanan Müslümanlar, Mekkeli müşriklerle yapılan Bedir, Uhud ve Hendek savaşları neticesinde sadece Mekke'ye değil bütün bir Arap Yarımadası'na karșı siyasi bir üstünlük de sağlamış oldular. Diğer taraftan Medine dişındaki insanlar ya bulundukları yerde ya da Medine'ye gelerek İslam'ı tercih ediyorlardı. Bütün bu gelişmeler sayesinde Müslümanlara yapılan baskılar ortadan kalkmış, dinin esasları kolayca öğrenilme ve tebliğ edilme imkânı bulmuştur. Nihayetinde Mekke'nin fethiyle Arap Yarımadası'nda tam bir hakimiyet kuran Müslümanlar için artık hicret bir zorunluluk olmaktan çıkmıştır. Bundan sonra hicret, dâru'l-harbda bulunan ve çıkmaya gücü yeten Müslümanların oradan ayrılarak dâru'l-İslama göçmeleri şeklinde anlaşılmıştır. Bu anlamda hicretin kıyamete kadar devam edeceği konusunda ulema ittifak etmiştir. ${ }^{79}$ Dolayısıyla bulundukları yerde inançlarını açığa vuramayanların, dinin emirlerini gereği gibi ifa edemeyenlerin bütün bunları yapabileceği bir yerin bulunması durumunda güç yetirebiliyorsa oraya hicret etmeleri farzdır. Güç yetirebildikleri halde bulundukları yerde kalmaları ise haramdır. "Iman edip de hicret etmeyenlere gelince, onlar hicret edinceye kadar sizin onlara hiçbir şeyle velâyetiniz yoktur." mealindeki ayetle, imkânları olduğu halde hicret etmeyenleri kınayan "Allah'ın arzı geniş değil miydi, hicret etseydiniz ya!"81 ayeti buna işaret etmektedir. Diğer taraftan "gücü yetenlerin farzları yerine getirmeleri bir zorunluluk olmakla birlikte farzların kendisiyle tamamlanabileceği şeyler de farzdır." ${ }^{2}$ kaidesi gereği bulunduğu yerde farzları yerine getirmeyen kimse için bu imkânın olduğu yere hicret etmek farz olur.

Peygamber (s.a.v.) “Ey Allah'ın Rasulü! Hicret üzere babama biatta bulundum" diyen sahabiye "Onunla cihad üzere biatta bulun, hicret artık sona erdi." 83 buyurarak Mekke'nin fethiyle birlikte Müslümanların güçlendiğine işaret ederek zorunlu olan hicretin son bulduğunu ifade etmiştir. Ayrıca "Fetihten sonra hicret yoktur. "84 buyurarak da bu hükmü teyit etmiştir. 85

Mekke'nin fethiyle hicretin son bulduğuna işaret eden bu hadislerin yanı sıra hicretin kıyamete kadar devam edeceğini ifade eden rivayetler de vardır. $\mathrm{Bu}$ rivayetlerden birinde Muâviye, Allah Rasulü'nün şöyle dediğini nakleder: "Tövbe

\footnotetext{
79 el-Mevsuatül-fikhiyye (mv.f.), "Hicret" md., XLII, 184; Ahmet Özel, “Hicret”, TDV Íslam Ansiklopedisi, (DIA), XVII, 464.

Enfâl 8/72.

Nisa $4 / 97$.

Ebu Hamid Huccetülislam Muhammed b. Muhammed Gazzalî, el-Müstasfa min ilmi'l-usul, Beyrut: Dâru'n-nefais, 2011, I, 204.

Nesâî, "Bey'at", 9.

Dârimî, "Siyer", 69; Tirmizî, "Siyer", 33.

el-Mevsuatü'l-fikhiyye (mv.f.), "Hicret" md., XLII, 180
} 
sona ermedikçe hicret sona ermez, güneş batıdan doğuncaya kadar da tövbe son bulmaz." ${ }^{\prime 6} \mathrm{Bu}$ konudaki bir diğer hadiste de "Kâfirlerle savaş devam ettikçe hicret sona ermez" 87 buyrulmaktadır. Yine bir başka rivayette ise şöyle buyurulmaktadır: "Mekke fethinden sonra hicret mecburiyeti kalkmıştır; lâkin cihad ve iyi niyetle yurdundan ayrılmanın gerekliliği devam eder; bu sebeple savaşa çağırıldı̆̆ınız zaman hemen katılın." ${ }^{\prime 8} \mathrm{Bu}$ hadis, İslam dininin açlkça yaşanabilir olduğu yerler var olduğu müddetçe hicretin bir zorunluluk olmaktan çıtığına işaret etmektedir. Diğer taraftan Hz. Peygamber'in "Fetihten sonra hicret yoktur." ifadesi her ne kadar zahirde mutlak ise de, "Medine'ye" diye kayıtlamak gerekmektedir. Çünkü yukarıdaki rivayette de görüldüğü üzere düşmanla cihad yapıldığı müddetçe hicrete ihtiyaç duyulacak ve meşru varlığını kıyamete kadar devam ettirecektir

$\mathrm{Bu}$ farklı rivayetler nedeniyle fukaha fetihten sonra hicretin hükmünde ihtilaf etmişlerdir. Bu ihtilafları genel olarak şu şekilde özetlemek mümkündür:

1. Ebu Hanife'nin de benimsediği görüşe göre ilk başta hicret müstehaptı; ancak Hz. Muhammed (s.a.v.)'in Müslümanlarla birlikte Medine'ye hicretiyle beraber farz oldu. Fakat fetihle Medine'ye hicreti gerekli kılan şartlar son bulunca hicretin hükmü ilk haline dönmüştür. ${ }^{89}$

2. Hicretin farziyeti Mekke'nin fethiyle birlikte düşmüştür. Çünkü Mekke dâru'l-İslam olmuştur. Bundan sonra ise ancak dâru'l-harbdan dâru'l-İslama hicret farz olarak kalmıştır. ${ }^{90}$

3. Müslümanların her şeyini bırakarak Medine'ye hicret etmeleri en faziletli hicrettir. Fetihten sonraki hicret ise kötülükleri terk etmektir ki bu kıyamete kadar devam edecektir. ${ }^{91}$

$\mathrm{Bu}$ görüşlerden anlaşıldığına göre ulema arasında Medine'ye hicretin farziyeti hususunda ve fetihten sonra kötülükleri terk etme ve dâru'l-harbdan dâru'l-İslama hicretin gerekliliği üzerinde ittifak vardır. Bu ittifakla, hicretin sona erdiğine dair rivayetler ile tenakuz halindeymiş gibi görünen hicretin devam edeceğine dair rivayetler telif edilmiştir.

Diğer taraftan hicretin amacı göz önünde bulundurulduğunda dâru'l-harbda baskıya maruz kalmadan dinini serbestçe yaşayan Müslümanların hicret etmek zorunda olmadıkları da gözden ırak tutulmamalıdır. Nitekim Hz. Muhammed'in, Mekke'de ikametinin devamına izin verdiği amcası Abbas'ın durumu, dâru'l-harbda

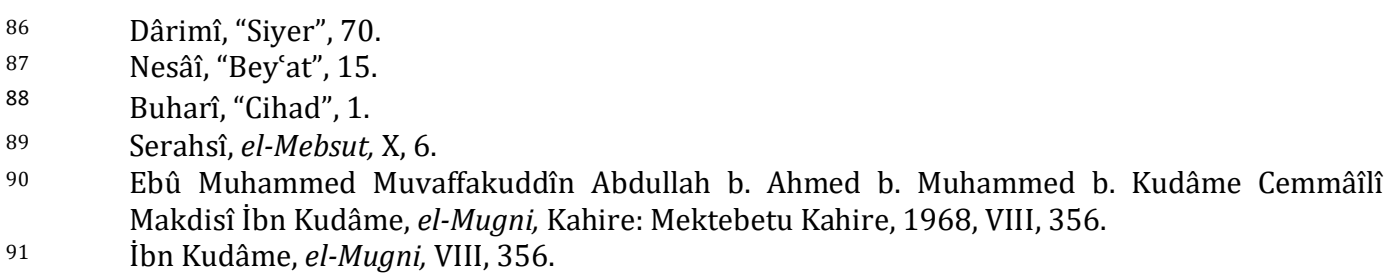


dinin emirlerini yerine getirmeye gücü yeten bir Müslüman için hicret etmenin farz olmadığına işaret etmektedir. ${ }^{92}$

Yukarıda da belirtildiği üzere Şafii âlimlerine göre dâru'l-harbda dinini açıkça yaşayabileceğine ve orada inancını kolayca yayabileceğine inanan bir Müslümanın bulunduğu yerde kalması hicret etmesinden efdaldir. Hatta hicret etmesinin inancı bakımından kendisine ve Müslümanlara bir faydası olmayacağına dair bir kanaat hasıl olursa dâru'l-harbda kalması farzdır. Yine Şafii ulemasına göre dâru'l-harbda Müslüman can ve mal güvenliğinin yanı sıra tek başına inancını yaşamaya ve yaymaya güç yetirebildiği sürece onun bulunduğu yer dâru'l-İslam sayılır; orayı terk etmesi durumunda o yer dâru'l-harba dönüşecektir. Bu nedenle orayı terk etmesi câiz olmaz. ${ }^{93}$

Bütün bunlardan anlaşılan genel anlamda hayat şartlarının zorunlu kıldığ göç ve bu şartlara ilaveten dinin gereklerinin zorunlu kıldığı özel bir göç tipi olan hicret klyamete kadar var olmaya devam edecektir. Bu durumda asıl tartışılan konu şartlan bir hayli farklı günümüz dünyasında hicreti zorunlu kılan durumlar ve hicretin imkânıdır. Bir başka deyişle tarihi uygulamaların da ışığında, uluslararası şartlar çerçevesinde Müslüman olmayan bir topluluk içinde Müslüman olan bir kimsenin veya düşman işgaline maruz kalan bir İslam ülkesinde hicret bakımından Müslümanların durumlarının ne olacağıdır. ${ }^{94}$ Son olarak bu durumu ele almayı uygun bulduk.

\subsection{Gayrimüslim Ülkelere Hicretin Hükmü}

Hicret şartların zorunlu kıldığı bir durum olması hasebiyle hüküm itibariyle asıl olan değil sonradan meydana gelen bir durumdur. Canını korumak, inancını izhar etmek, siyasi otoriteyi sağlayacak devleti kurmak, tebliğ görevini ifa etmek ve geçimini sağlayacak işleri yürütebilmek hicreti zorunlu kılan durumların başında gelmektedir. Bu amaçlar doğrultusunda bulunduğu ülkede baskı gören ve inancını yaşayamayan bir Müslüman'ın bir başka ülkeye hicret etmesi, baskının ve zorluğun durumuna göre mubah, müstehap mekruh, vacip ve haram gibi hükümler alır. Bu hükümler Müslüman'ın dâru'l-İslamı terk etmesi bakımından önemli olduğu kadar gideceği ülkenin tayininde de belirleyici unsur olacaktır. Zira gideceği ülke bulunduğu ülkeden dini hayat bakımından daha güvenli değilse çıtığı yolculuk hicret olarak değer kazanmayacaktır. Mesela, yaşadığı ülkede ikrah-ı mülci derecesine ulaşmamış olan birtakım baskılar olsa da tek başına veya akrabalarının yardımıyla bu baskıların üstesinden gelebilen, kendi ülkesinde rızkını temin edebilecek iş imkânları bulabilen, bulunduğu yerde kalması kendi zararına olsa bile ümmetin menfaatine olan kimselerin hicret etmek yerine ülkesinde kalıp o baskıları

92 Ebü'l-Mehasin Yusuf b. Musa Hanefi, el-Mu'tasar mine'l-Muhtasar min Müşkili'l-asar, Beyrut: Âlemü'l-Kütüb, t.y., I, 222.

93 Remlî, Nihayetü'l-muhtac, VIII, 82; el-Mevsuatü'l-fikhiyye (mv.f.), "Hicret” md., XLII, 183.

94 Mustafa Aydın, "Özel Bir Göç Biçimi Olarak Hicret”, Sosyoloji Divanı, Sayı: 6, (Temmuz-Aralık, 2015), s. 112. 
bertaraf etmek için mücadele etmesi gerekmektedir. Hal böyle olunca ancak yukarıda belirtilen durumların daha kötüsü yaşanması durumunda, öncelikle varsa daha güvenli olan bir başka İslam beldesine yoksa gayrimüslim bir ülkeye yapılan göç, hicret olarak değerlendirilebilir.

Dinî hayatın gerekli kıldığı hicret bir zorunluluk olmakla birlikte günümüzde yaşanan hayat ve devletlerarası münasebetler bunun o kadar da kolay olmadığını ortaya koymuştur. Zira bir ülkeden başka bir ülkeye geçmek isteyen kişi için hem ayrılacağı ülkenin hem de gideceği ülkenin giriș çıkışlarda uyguladığı işlemler bazen hicret ve benzeri amaçlı göçleri neredeyse imkânsız kılmaktadır. Böylece iradî bir fiil olan hicret, şartların ve kanunların etkisiyle insan iradesini aşan bir durum haline dönüşmekte ve daha karmaşık bir hal almaktadır.

Genel olarak dâru'l-küfr yani gayrimüslimlerin hâkimiyeti altında bulunan ülkeler ve toplumlar Müslümanların yaşamlarını sürdürmeleri için uygun olmayan çevrelerdir. Çünkü dâru'l-küfre giden bir Müslüman onların kanunlarına tabi olmak, emirlerine boyun eğmek ve onların örf adetlerine göre yaşamak zorunda kalabilir. İslam'ın şiarından olan ezan sesinden ve ibadetleri gereği gibi yapmaktan mahrum olabilir. Vereceği vergilerle, yapacağı ticaretle ve harcamalarla gayrimüslimlerin güçlenmesine katkı sağlar. Bu nedenle Malikî âlimlerden Sahnûn, küfrün hâkim olduğu bölgelerde ticaret yapmanın, başka imkânlar olduğu halde gayrimüslimlerin gemisine binmenin dâhi uygun olmadığını söylemiştir. ${ }^{95}$ Ayrıca İslam'ın itikadıyla çelişen inanışlar, haramlarını mubah gören kanunlar ve alânen işlenen masiyetler, dinin makasıdından olan din, mal, nesil ve akıl gibi değerleri daima tehdit eder. Diğer taraftan Gayrimüslim ülkede yetişen çocuklar ve gençler onların eğitim sisteminde İslam'ın terbiyesinden uzak yetişir ve bulundukları çevrenin etkisiyle İslam kültürüne yabancılaşırlar. Bütün bunlar şeref, izzet ve azamet sahibi dinin mensupları olan Müslümanlar için bir zillettir. Maliki fukahasından Venşerîsi'ye (ö. 914/1508) göre Müslümanlar, dâru'l-küfürde hakarete uğrama, zillete düşme, hor görülme, kandırılma, alay edilme gibi olumsuz tutum ve davranışlara maruz kalırlar. Ayrıca gayrimüslimlerle yapılan anlaşmalara güvenilmeyeceği için küfür diyarında Müslümanların canları ve malları daima tehdit altındadır. ${ }^{96}$ Aslında Venşerîsi bu görüşleriyle Müslümanların dâru'l-harbda yaşamasının imkânsız olduğunu ifade etmek istiyor. Bir diğer ifadeyle dâru'lharbda șerefli, itibarlı bir hayat sürdürmenin, can ve mal yönünden güvende olmanın hiçbir zaman garantisi olmayacağına dikkat çekiyor. ${ }^{97}$ Dolayısıyla asıl olan, Müslümanların dâru'l-İ́slam'da yaşamalarıdır veya dâru'l-küfürde iseler buradan dâru'l-İslama göç etmeleridir. Aksi ise normal şartlarda mekruh 98 veya haram kabul edilmiştir. Nitekim "Zulmedenlere

95 Ebü'l-Velid Süleyman b. Halef el-Bacî, el-Münteka şerhu'l-Muvatta, Beyrut: Daru'l-kütübi'lArabî, 1985, III, 187.

96 Ebü'l-Abbas Ahmed b. Yahyâ et-Tilimsani Venșerisî, Miyarü'l-mu'rib ve'l-camii'l-Magrib, Beyrut: Dârü'l-Garbi'l-İslâmî, 1981, II, 139-140.

97 Muammer Arangül, "Gayrimüslim Hâkimiyeti Altında Yaşamanın Fıkhî Açıdan İmkânı Üzerine”, Hitit Üniversitesi İlahiyat Fakültesi Dergisi, 2017/2, s. 445. 
meyletmeyin. Yoksa size de ateş dokunur. Sizin Allah'tan başka dostlarınız yoktur. Sonra size yardım da edilmez." "99 ayeti ve daha başka ayetler ${ }^{100}$ bu duruma da işaret etmektedir. "Ancak günümüzde hem siyasi anlamda hem de kültürel anlamda Müslümanların hâkim oldukları ülke ve toplumlarda belli bir dinî anlayış ve yaşayışa karşı baskılar yapılabilmekte buna karşı gayrimüslimlerin hâkim oldukları ülkelerde din ve vicdan hürriyetinin sınırları daha geniş olabilmektedir. Bu sebeple göç ve beraber oturma mecburiyetini 'siyasî ve kültürel hâkimiyet' yerine 'din, düşünce ve vicdan hürriyetine' bağlamak günümüz için daha geçerli gözükmektedir." ${ }^{101}$ Her ne kadar bu anlamdaki göçü istılahî anlamda hicret olarak isimlendirmek zor olsa da "can güvenliği ve dini yaşama özgürlüğü" bağlamında amaçları bakımından hicret kavramının kapsamına dahil etmek mümkün gözükmektedir. Bu konuda en dikkat çekici husus başta can güvenliği olmak üzere çalışma, öğrenim görme ve inancının gereklerini daha özgürce yaşama gibi amaçlarla ülkesini terk etmek zorunda kalan veya kendi isteğiyle İslâm beldelerinden Batı ülkelerine giden Müslümanların durumudur. Geçmişte de benzeri durumların yaşandığı, ulema arasında tartışılan fıkhi meselelerden anlaşılmaktadır. Zira klasik fıkıh literatüründe dâru'l-harbe giden ve orada define bulan bir Müslümanın durumu102, orada bulunduğu sürece zekât mükellefiyeti ${ }^{103}$ ve ehli kitapla evlenmesi ${ }^{104}$ gibi konuların tartışıldığını görmekteyiz. $\mathrm{Bu}$ türden bir göçün meşruiyetine dayanak oluşturabilecek nitelikte olması hasebiyle bazı araştırmacıların Habeşistan'a hicreti referans göstermektedirler. ${ }^{105}$

Bu çalışmada da kabul edildiği üzere Habeşistan'a hicretten hareketle küfür diyarına hicret etmeyi meşru bir temele oturtmak mümkün gözükmekle beraber bazı farklılıkların da bulunduğunu kabul etmek gerekir. Zira o dönemde dünya üzerinde dâru'l-İslam niteliklerini taşıyan bir ülke bulunmamaktaydı. Ayrıca Mekke dâru'l-küfr olmanın yanı sıra aynı zamanda Müslümanlara açıç̧a zulüm yapılan bir yerdi. Bu durumda Habeşistan'a hicret, zulmün hâkim olduğu dâru'l-küfürden adaletin hâkim olduğu dâru'l-küfre hicret demektir. Kaldı ki Habeşistan'a hicret emrini Peygamberimizin vermiş olması ayrıca önem arz etmektedir.106

Gayrimüslim ülkelere hicret açısından Nisa suresinin 95-100. ayetleri önemli ilkelere dikkatimizi çekmektedir. Zira bu ayetlerde, Allah rızası için dinini öğrenip yaşayabileceği ve yayabileceği bir yere hicret eden ve gittiği yerde mücadele ederek maddî ve manevî değerlerini koruyan müminler övülmüştür. Bu nedenle bazı araştırmacılar dâru'l-küfürde ikameti İslam dinini yayma ve dinin hakikatlerini

\footnotetext{
$99 \quad$ Hud, $11 / 113$.

100 Bkz. Mümtehine 60/1-4; Enfal 8/72-73.

101 Karaman-Çağrıcı-Dönmez-Gümüș, Kur'an Yolu, II, 126-127.

102 Serahsî, el-Mebsut, II, 215.

103 Serahsî, el-Mebsut, III, 37.

104 Serahsî, el-Mebsut, V, 50; X, 96.

105 Bkz. Muhammad Khalid Masud, "Gayr-i Muslim Bir Devlette Müslüman Olmak”, s. 207-208; Necmeddin Güney, "Maliki Fakih İbn Ebî Cum’a El-Mağrâvî'nin İspanyol Zulmü Altındaki Endülüs Müslümanlarına (Moriskolara) Gönderdiği İkrah/Takıyye Fetvası", İslam Hukuku Araştırmaları Dergisi, 31 (2018), s. 273; Özel, "Hicret", XVII, 466.

106 Selkînî, el-Hicretü ve ahkâmuha, s. 197-198.
} 
insanlara anlatma hususunda büyük bir firsat olarak görmüşler, Müslümanların bu gibi ülkelerden ayrılmasını uygun bulmamışlardır. ${ }^{107}$ Ancak Ayyaş b. Ebû Rebîa ${ }^{108}$ gibi hicret etme imkânı olmayan mustazaflar dışında imkânı bulunduğu halde dinî hayatları için tehlike teșkil eden çevrede yaşamaya devam edenler kınanmış ve ceza görecekleri bildirilmiştir.109

Hicretin gayesini dikkate alarak gayrimüslim ülkelere hicreti meşru kılabilecek sebepleri şu şekilde sıralayabiliriz:

1. Gayrimüslim ülkelere hicreti mubah kılabilecek durumların başında zaruretler gelir. Dini, canı, malı, nesli ve aklı koruma gibi zaruri veya zaruret menzilesinde sayılabilecek hâcî maslahatlar söz konusu olduğunda bir Müslüman, Müslümanlarla fiili harp halinde bulunmayan küfür diyarına gidebilir. $\mathrm{Bu}$ gibi durumlarda "Zaruretler kendi miktarınca taktir olunur."110 külli kaidesinin önemli bir sinırlandırıcı ilke olduğu gözden ırak tutulmamalıdır. Ayrıca böyle bir hicretin meşruiyeti "Bir özür için caiz olan şey, o özrün zevaliyle bâtıl olur."111 ilkesi gereği zorunlu durumların varlığıyla sinırlıdır. $\mathrm{Bu}$ zorunlu durumların başında Ebu Hanife'nin de hicret için işaret ettiği "güven ve emniyet" durumunun kalmaması gelmektedir. Nitekim bulunduğu ülkede, baskı ve zulüm sebebiyle canı, malı ve dini hayatı tehdit altında olan kişi için hicretin bir zorunluluk olduğu aşikârdır.

2. Birinci maddede belirtilen gerekçenin devamı olarak zorunlu durumlarda gayrimüslim bir ülkeye gitmenin meşruiyeti gidecek başka bir İslam ülkesinin bulunmamasına bağlıdır.

3. Gayrimüslim bir ülkeye hicreti meşru kılacak en önemli sebeplerden biri de İslâm'ı tebliğ etmek olsa gerekir. Ama bu görevin yapılabileceğinden emin olunmalıdır.

4. Her ne kadar tam olarak ne kastedildiği fukaha tarafından ifade edilmemiş olsa da "dinin izhar edilmesi" küfür diyarına göçün veya orada ikametin meşru bir gerekçesi olabilir. Zira dinin izhar edilmesinden sadece namaz ve oruç gibi ibadetlerin serbestçe yapılabilmesi anlaşılabileceği gibi ezanın okunması ve namazın cemaatle kılınması ya da daha geniş manada İslam hukukunun uygulanması da anlaşılabilir. ${ }^{112}$

Süleyman Muhammed Tubulyak, el-Ahkâmü's-siyasiyye li'l-ekalliyati'l-müslime fi'l-fikhi'lİslâmî, Amman: Dârü'n-Nefâis, 1997, s. 53.

Ebû Cehil'in kardeşi Ayyaş b. Ebû Rebîa müslüman olunca Medine’ye hicret etmiş; ancak daha Medine'ye varmadan Ebu Cehil ve diğer kardeşleri tarafından geri çevrilmişti. Mekke’ye getirilen Rebîa hapsedilerek çeșitli işkencelere maruz bırakılmıștı. Mekke'nin fethiyle özgürlüğüne kavuşan Ayyaş Medine'ye gitmiş ve Yermük'te şehit olmuştur. Bkz. Ebû Ömer Cemaleddin Yusuf b. Abdullah b. Muhammed Kurtubi İbn Abdülber Nemeri, el-İstiab fí ma'rifeti'l-ashab, Beyrut: el-Mektebetü'l-Asriyye, 2010, II, 254.

Bkz. Nisa, 4/95-100.

Mecelle-i Ahkâmi Adliyye, (haz. Ali Himmet Berki), Hikmet Yayınları, İstanbul, 1982, md., 21. Mecelle, md., 23.

Bkz. Arangül, "Gayrimüslim Hâkimiyeti Altında Yaşamanın Fıkhî Açıdan İmkânı Üzerine”, s. 451-452. 
5. Müslüman toplumların kalkınmasını sağlamak amacıyla modern bilim ve teknolojiyi öğrenip İslam ülkesine taşımak için bu ülkelere gitmenin yalnızca mubah değil bütün ümmetin maslahatı için aynı zamanda gerekli olduğu da açık bir gerçektir. Ancak böyle durumlarda "Zarar-ı amını def için zarar-ı has ihtiyar olunur."113 ve "Zarar-ı eşed zarar-ı ehaf ile izâle olunur."114 kaideleri dikkate alınmalı ve maslahatın varlığından ve mefsedete göre daha baskın olduğundan emin olunmalıdır.

6. Dinî, siyasî ve askerî birtakım maslahatları sağlamak, ticarî ilişkileri geliştirmek, iş ve çalışma imkânları bulmak da böyle bir hicretin meşru gerekçesi olabilir. ${ }^{115}$

7. Hicret eden kişi, kendisinin ve beraberindeki aile efradının gittiği yerde fitneye düşme, gayrimüslimlerin inanç ve adetlerinden etkilenme, itikadının ve ahlakının bozulması gibi tehlikelerden emin olmalıdır. 116

Nihayetinde bütün bu gerekçeleri bir hicret sebebi kllacak unsurun ise kişinin niyeti olduğu da unutulmamalıdır. Yani her ne gerekçeyle hicret etmiş olursa olsun kişi bu durumun geçici olduğunu bilmelidir. Çünkü asıl olanın kişinin kendi vatanında Müslümanlarla birlikte yaşamasıdır.

\section{Sonuç}

İnsanlık tarihinin vazgeçilmez olgularından biri olan hicret, temelde iki anlamda kullanılmaktadır. Bunlardan biri gerçek anlamıyla bir yerden bir yere göç etmek diğeri ise manevi anlamda kötülükleri terk etmektir. Ancak hicret, zamanla özel bir anlam kazanarak Hz. Muhammed (s.a.v.) ile Müslümanların Medine’ye 622 yılında gerçekleştirdikleri kutsal göç için kullanılan bir isim olmuştur.

İlahi iradenin belirlediği hedefler doğrultusunda gerçekleşen hicretler daima, inananlar için zulüm ve baskıdan kurtulmanın yanı sıra yeni imkânları sağlayan birer firsat olmuştur. Medine'ye hicrette olduğu gibi muhacirler gittikleri yerlere götürdükleri barış ve huzurla oraların medeniyetine katkıda bulunmuşlardır.

Hicretin temel hedefi baskı ve zulümden uzak bir şekilde yurt edinip dinin emirlerini rahatça yaşayabilmek ve dinin tebliğini olabildiğince daha çok insana ulaştırmaktır. Bu nedenle Müslümanın vatanı, inancını özgürce ızhar edebileceği, kulluğunun gereklerini kolaylıkla yerine getirebileceği yerdir. Aksi durumlarda bulunduğu yerde kalmamalı, kulluğunu serbest yapabileceği yere gitmelidir. Hicret ederek zorluktan kolaylığa, darlıktan genişliğe çıkmak, zulümden kaçarak adalete sığınmak ve baskıdan kurtulup özgürlüğe kavuşmak için ne gerekiyorsa yapmak ve

\footnotetext{
$113 \quad$ Mecelle, md., 26.

$114 \quad$ Mecelle, md., 27.

115 Selkînî, el-Hicretü ve ahkâmuha, s. 192-193.

116 Selkînî, el-Hicretü ve ahkâmuha, s. 192-194-195.
} 
nihayetinde iyi bir kul olmak Müslümanın asıl amacı olmalıdır. Bu prensipler aynı zamanda Müslüman için hicretin hükmünü de tayin etmektedir.

Mekke'den Medine'ye hicretin hükmünün farziyeti üzerinde ittifak eden ulema fetih sonrası için ihtilaf etmişlerdir. Ancak genel kanaat Medine'ye hicretin şartları gerçekleştiği sürece hicretin de farz olacağı yönündedir. Bu anlamdaki hicret ile manevi anlamda Allah'ın yasaklarından kaçma hicreti kıyamete kadar önemini koruyarak devam edecektir.

Dâru'l-harpta dinin gereklerini rahatça yaşayabilenlerin hatta orada bulundukları sürece dini tebliğ görevlerini serbestçe yapabilenlerin orada kalmaları hicret etmelerinden elzem görülmüştür.

Hicret normalde dâru'l-harptan dâru'l-İslama doğru gerçekleşen bir göçtür. Ancak günümüzde Müslümanların hakimiyeti altında bulunan bazı ülkelerdeki dini yaşamı tehdit eden durumlar Müslümanları, bu anlamda din ve vicdan hürriyetine yönelik baskıların daha az olduğu ama gayrimüslimlerin hâkim bulundukları ülkelere hicreti gündeme getirmiştir.

Şartları bakımından birebir aynı olmasa da Habeşistan'a hicretten hareketle gayrimüslim ülkelere hicretin; can ve mal güvenliğini sağlama, dinin gereklerini rahatça uygulayabilme, tebliğ ve eğitim gibi bazı zorunlu sebepler çerçevesinde geçici olmak kaydıyla meşru olacağında şüphe yoktur.

Hayatın idamesinin zorunlu kıldığg zaruret durumu ve gidecek başka İslam ülkesinin olmayışı gayrimüslim ülkelere hicreti meşru kılacak bir diğer sebep olarak gösterilebilir. Ayrıca Müslüman toplumların kalkınmasını sağlamak amacıyla modern bilim ve teknolojiyi öğrenip İslam ülkesine taşımak da hicretin meşruiyet sebebi olarak zikredilebilir. Bir de dinî, siyasî ve askerî birtakım maslahatları sağlamak, ticarî ilişkileri geliştirmek, iş ve çalışma imkânları bulmak da böyle bir hicretin meşru gerekçesi olabilir.

Hangi gerekçeyle olursa olsun gayrimüslim ülkelere hicret geçici olmalıdır.

Hicret eden kişi, kendisinin ve beraberindeki aile efradının gittiği yerde fitneye düşme, gayrimüslimlerin inanç ve adetlerinden etkilenme, itikadının ve ahlakının bozulması gibi tehlikelerden emin olmalıdır.

Nihayet kişi gittiği yerde dinini izhar edebilmeli, dinin izzetini, şerefini ve değerini koruyarak yaşamını sürdürebilmelidir. Aksi taktirde yukarıda belirtilen hiçbir sebep hicret için bir meşruiyet dayanağı oluşturmaz. 


\section{Kaynakça}

Apak, Âdem, “Hz. Peygamber'in Hicret Sonrası Medine'de Örnek Toplum Oluşturma Adımları Üzerine”, Hz. Muhammed ve Evrensel Mesajı Sempozyumu, Nisan, 20-22 2007 (Yay. Haz. Mahfuz Söylemez), Ankara: İslami İlimler Dergisi Yayınları, 2007, s. 315-324.

Arangül, Muammer, "Fıkıh Literatüründe Klasik Ülke Terminolojisi ve Güncel Değeri", Şırnak Üniversitesi İlahiyat Fakültesi Dergisi, 2017/2, s. 7-34.

Arangül, Muammer, "Gayrimüslim Hâkimiyeti Altında Yaşamanın Fıkhî Açıdan İmkânı Üzerine”, Hitit Üniversitesi Illahiyat Fakültesi Dergisi, 2017/2, s. 433-461.

Aydın, Mustafa, "Özel Bir Göç Biçimi Olarak Hicret", Sosyoloji Divanı, Sayı: 6, (Temmuz-Aralık, 2015), s. 103-114.

Baberti, Ekmeleddin Muhammed b. Muhammed b. Mahmûd b. Ahmed, İnaye șerhi'l-hidaye, Beyrut: Dâru'l-fikr, t.y., I-X.

Baci, Ebü'l-Velid Süleyman b. Halef, el-Münteka șerhu'l-Muvatta, Beyrut: Daru'l-kütübi'lArabî, 1985, I-VII.

Cürcani, Seyyid Şerfi, “Hicret” md., et-Ta'rifat, Beyrut: Dâru'l-kütübi'l-ilmiyye, 1983.

Demir, Mehmet, "Bir İtaat Eylemi Olarak İslâm'da Hicret ve Muhacirler", Illahiyat Akademi Dergisi, 3/4 (2016),159-183.

Demircan, Adnan, "Hz. Peygamberin Hicreti”, İslam Tarihi Araştırmaları Dergisi, $1 / 1$ (2017), 1-33.

Desuki, Muhammed b. Ahmed b. Arafe, Hâsşiyetü'd-Desûkî ala şerhi'l-kebîr, Beyrut: Dâru'l-fikr, t.y., I_IV.

Ebü'l-Mehasin Yusuf b. Musa Hanefi, el-Mu'tasar mine'l-Muhtasar min Müşkili'l-asar, Beyrut: Âlemü'l-Kütüb, t.y., I-II.

el-Mevsuatü'l-fikhiyye (mv.f.), "Dâru'l-harb” md., Kuveyt: Vizaretü'l-Evkaf ve'ş-Şuuni'lİslâmiyye, 2004, XX, 205-216.

el-Mevsuatü'l-fikhiyye (mv.f.), "Hicret” md., Kuveyt: Vakıflar Bakanlığı, 2004, XLII, 177-192.

Gazzali, Ebu Hamid Huccetülislam Muhammed b. Muhammed, el-Müstasfa min ilmi'l-usul, Beyrut: Dâru'n-nefais, 2011, I-II.

Güney, Necmeddin, “Maliki Fakih İbn Ebî Cum’a El-Mağrâvînin İspanyol Zulmü Altındaki Endülüs Müslümanlarına (Moriskolara) Gönderdiği İkrah/Takıyye Fetvası”, İslam Hukuku Araştırmaları Dergisi, 31 (2018), s. 263-290.

İbn Kudâme, Ebû Muhammed Muvaffakuddîn Abdullah b. Ahmed b. Muhammed b. Kudâme Cemmâîlî Makdisî, el-Mugni, Kahire: Mektebetu Kahire, 1968, I-X.

İbn Aşur, Muhammed Tahir b. Muhammed b. Muhammed et-Tunusi, et-Tahrîr ve't-tenvîr, Tunus: ed-Dâru't-Tunisiyye, 1984, I-XXX.

İbn Dakikul'id, Ebü'l-Feth Takıyyüddin Muhammed b. Ali, İhkamü'l-ahkâm şerhi Umdeti'lahkâm, Beyrut: Âlemü'l-Kütüb, 1987, I-II.

İbn Kayyim el-Cevziyye, Ebû Abdullah Şemseddin Muhammed, er-Risâletü't-tabukiyye: Zadü'l-muhacir ila Rabbihi, (thk. Mahmud Cemil Gazi), Cidde: Mektebetü'l-medeni, t.y., s. 16.

İbn Kayyim el-Cevziyye, Ebu Abdullah Şemseddin Muhammed, Ahkâmu ehli'z-zimme, (thk. Yusuf b. Ahmed el-Bekri ve Şakir b. Tevfik el-Aruri), Demmam: Ramadi li'n-neşr, 1997, I-III.

İbn Manzur, Ebü'l-Fazl Muhammed b. Mükerrem b. Ali el-Ensârî, "Hcr" md., Lisanü'l-Arab, Beyrut: Dâru Sadr, h. 1414, I-V.

İbn Ruşd el-Kurtubi, Ebu'l-Velid Muhammed b. Ahmed b. Muhammed, el-Mukaddimâtü'lmümehhidât, (thk. Said Ahmed A'râb), Beyrut: Daru'l-Garbi'l-İslami, 1988, I-III. 
İbnü'l-Cevzi, Ebü'l-Ferec Cemâlüddîn Abdurrahmân b. Alî b. Muhammed Bağdâdî, Zadü'lmesir fî ilmi't-tefsir, (thk. Abdü'r-Rezzâk el-Mehdî), Beyrut: Dâru'l-kütübi'l-Arabiyye, h. 1422, I-IV.

Karaman, Hayrettin-Çağrıcl, Mustafa- Dönmez, İbrahim Kâfi- Gümüș, Sadrettin, Kur'an Yolu, Ankara: Diyanet İşleri Bașkanlığı Yayınları, 2006, I-V.

Kardavi, Yusuf, Flkhü'l-cihad: dirase mukarene li-ahkamihi ve felsefetihi fi dav'i'l-Kur'an ve'ssünne, Kahire: Mektebetu Vehbe, 2009, I-II.

Kâsânî, Alâuddin Ebu Bekr b. Mes'ud, Bedâi'u's- sanâi' fi tertibi'şsşerai', Beyrut: Dâru'lkütübi'l-ilmiyye, 1986, I-VII.

Maverdi, Ebü'l-Hasen Alî b. Muhammed b. Habîb Basrî, el-Ahkâmü's-sultaniyye, Kahire: Dâru'l-hadis, ty.

Masud, Muhammad Khalid, "Gayr-i Muslim Bir Devlette Müslüman Olmak: Üç Alternatif Model", İslam Hukuku Araştırmaları Dergisi, (Çev. Muammer Arangül), 18 (2011), s. 201-210.

Mecelle-i Ahkâmi Adliyye, (haz. Ali Himmet Berki), Hikmet Yayınları, İstanbul, 1982, Md., 23.

Nevevi, Ebû Zekeriyyâ Yahyâ b. Şeref b. Mürî, Ravzatü't-talibin, (thk. Adil Ahmed Abdülmevcud, Ali Muhammed Muavvaz), Riyad: Dâru âlemi'l-kütüb, 2003/1423, IVIII.

Önkal, Ahmet, "Hicret", TDV İslâm Ansiklopedisi (DIA), XVII, 458-462.

Özel, Ahmet, "Dârülharp", TDV İslam Ansiklopedisi, (DIA), VIII, 536-537.

Özel, Ahmet, "Hicret", TDV İslam Ansiklopedisi, (DİA), XVII, 462-464.

Özel, Ahmet, İslam hukukunda ülke kavramı dâru'l-İslam dâru'l-harb, İstanbul: İz Yayıncllık, 2011.

Ragıb el-İsfahani, Ebü'l-Kâsım Hüseyin b. Muhammed, "Hcr" md., el-Müfredat fí garibi'lKur'an, (thk. Muhammed Seyyid Kilani), Beyrut: Dâru'l-marife, t.y., s. 536-537.

Remli, Şemseddin Muhammed b. Ahmed b. Hamza el-Ensârî, Nihayetü'l-muhtac ila şerhi'lminhac, Beyrut: Dârü'l-fikr, 1984, I-VIII.

Selkînî, İbrahim Abdullah, el-Hicretü ve ahkâmuha, Lübnan: Dâru'n-Nevadir, 2014.

Serahsî, Ebu Bekr Muhammed b. Ahmed b. Ebî Sehl, el-Mebsut, Beyrut: Dâru'l-marife, 1993, IXXX.

Suyuti, Ebü'l-Fazl Celaleddin Abdurrahman b. Ebî Bekr, eş-Şemârih fi ilmi't-tarih, (thk. Abdurrahman Hasan Mahmud), y.y.: Mektebetü'l-Âdâb, t.y.

Şafiî, Ebû Abdullah Muhammed b. İdris b. Abbas, el-Ümm, Beyrut: Dâru'l-marife, 1990, I-VI.

Şirazi, Ebû İshak Cemaleddin İbrâhim b. Ali b. Yusuf, el-Mühezzeb fî fikhi'l-İmam eş-Şafii, Beyrut: Dâru'l-kütübi'l-ilmiyye, I-III.

Tehânevî, Muhammed b. A'la b. Ali el-Faruki el-Hanefi, Keşşafu istılahati'l-fünun, (thk. Ali Dehruc), Beyrut: Mektebetü Lübnan, 1996, I-II.

Tubulyak, Süleyman Muhammed, el-Ahkâmü's-siyasiyye li'l-ekalliyati'l-müslime fi'l-fikhi'lİslâmî, Amman: Dârü'n-Nefâis, 1997.

Wensinck, Arent Jean, "hcr" md., el-Mu'cemü'l-müfehres li-elfazi'l-hadisi'n-nebevi, (thk. Muhammed Fuâd Abdülbâkî), Leiden: Mektebetü Brill, 1936.

Venşerisi, Ebü'l-Abbas Ahmed b. Yahyâ et-Tilimsani, Miyarü'l-mu'rib ve'l-camii'l-Magrib, Beyrut: Dârü'l-Garbi'l-İ̇slâmî, 1981, I-XII.

Zühaylî, Vehbe, Asarü'l-harb fi'l-fikhi'l-İ́slâmî, Dımaşk: Dârü'l-fikr, 1983. 